\title{
Frankincense and Its Arabian Burner
}

\author{
William Gerard Zimmerle
}

1 Introduction

Arabia Felix, or Happy Arabia, ${ }^{1}$ has been memorialized throughout the ages on account of its smell. Some of the best-known aromatics associated with Arabia are the twin gum resins cut from the barks of the trees growing in the southernmost regions of the Arabian Peninsula that belong to the genera Boswellia and Commiphore of the Burseracaea family, otherwise known as frankincense and myrrh. From the Hellenistic period onward, these resins and their lucrative westward trade became the principal reference point for Arabia in the Mediterranean world. Indeed, this was so much the case that it is almost impossible for scholars to approach the question of Arabian trade prior to the Hellenistic period without presuming that this trade involved principally the gum resin frankincense, the most famous fragrant substance throughout history. In this chapter, I summarize the history of the frankincense trade through the lens of its principal container-the cuboid incense burner-used from the late Third Millennium B.C. until the present day in the Arabian Peninsula as the primary means to burn frankincense and other kinds of aromatics.

The cuboid containers mentioned here are square-shaped incense burners that have been recovered from archaeological excavations from every quadrant of the Middle East (figs. 1.1 and 1.2). They are testimony to a vast trade in Arabian aromatics that extended beyond the Peninsula to the Mediterranean world, on the one hand, and to
East Asia, on the other. ${ }^{2}$ As one important type of incense-related paraphernalia from Arabia, the cuboid-shaped censer is a historical and cultural object that becomes the focal point in exploring how the material culture evolves and lasts in cultural perpetuity throughout the ages. Pursuing this question requires an overview of the history of the Arabian trade in aromatics in general, and of frankincense in particular. I will begin by canvassing the proveniences of the cuboid incense burner, looking through space and time for its appearances in history, and then provide a historical overview of the aromatics trade in the Near East and a brief account of the production of incense burners today. Although incense burners have been found in archaeological excavations ranging geographically from the Levant to Mesopotamia, my focus here is only on items found along the trade routes running from the Arabian Peninsula to the Mediterranean markets, on the one hand, and to Mesopotamian city-states, on the other. As I will argue here, odors are a less analyzed but crucial part of the material culture of the Arabian Peninsula.

I will, therefore, begin with the question: How can historians and archaeologists detect patterns of olfaction use in history that are about burning combustible materials? Then, after reviewing both the material culture of cuboid incense burners in particular archaeological contexts and the historical evidence for the aromatics trade, I will pose anew the broader question taken from Igor Kopytoff's seminal article on the biography of things and
1 Jan Retsö, "When Did Yemen Become Arabia Felix?" Proceedings of the Seminar for Arabian Studies 33 (2003): 229.
2 Michael O'Dwyer Shea, "The Small Cuboid Incense Burners of the Ancient Near East," Levant 15, no. 1 (1983): 92. 


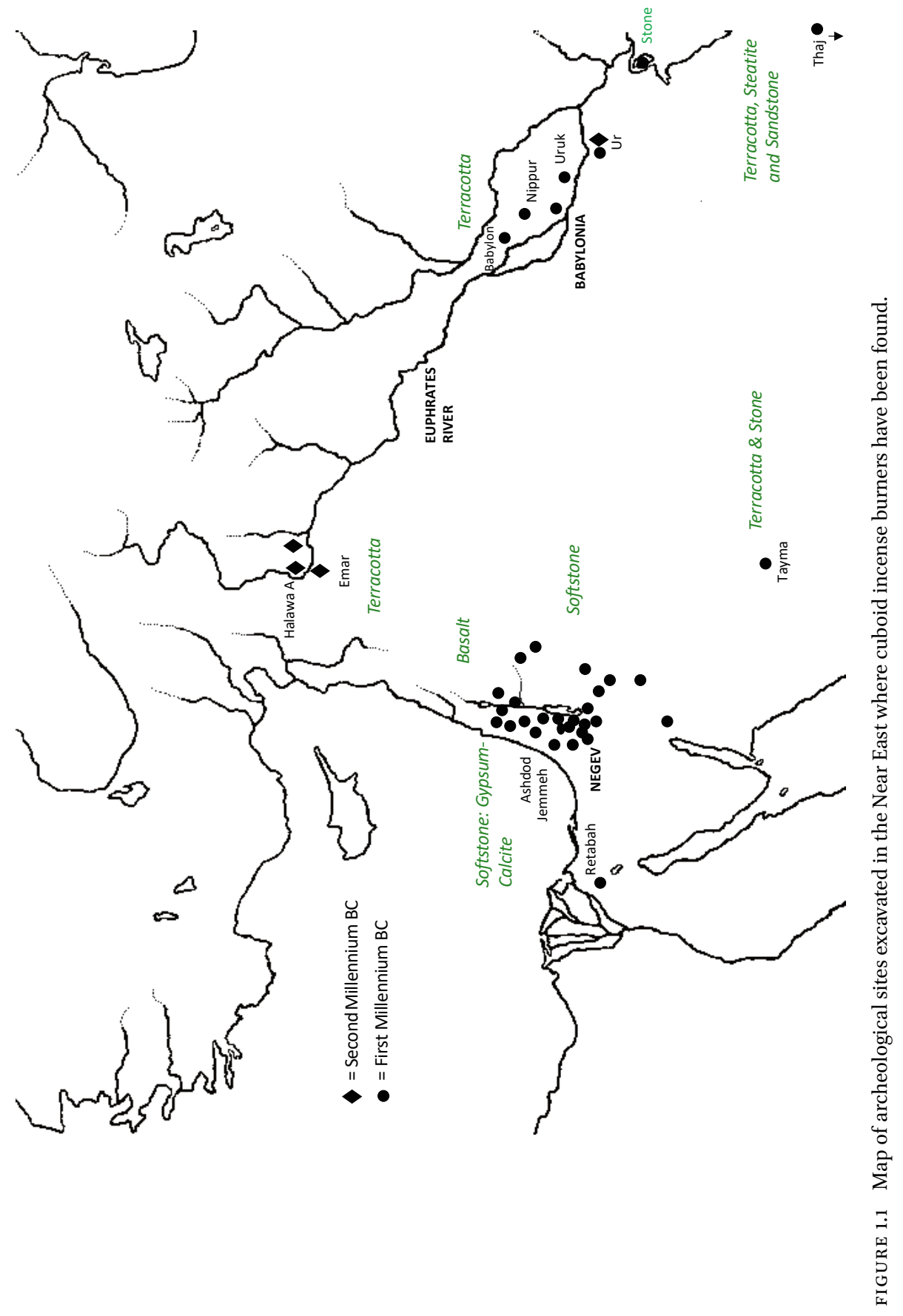




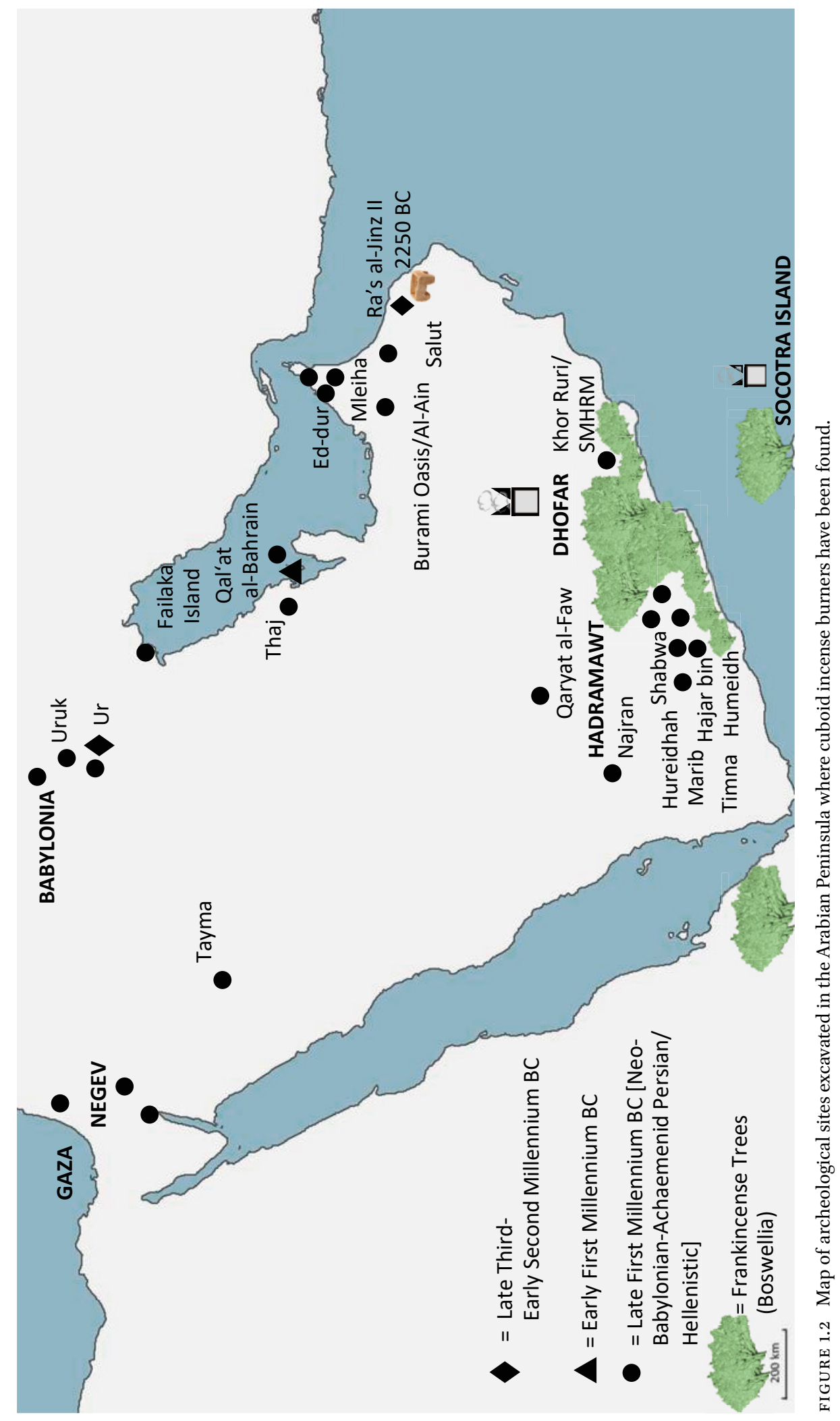


their cultural legacy: "Where does the thing come from and who made it?" 3

\section{$2 \quad$ Ra's al Jinz and Its Environment}

The history of the four-legged cuboid incense burner, sometimes identified as the frankincense burner, begins in the Arabian Peninsula. Excavations conducted at the coastal fishing town of Ra's al Jinz in the Sultanate of Oman uncovered artifacts that at first were unrecognized by the Western archeologists excavating the site (fig. 1.3). ${ }^{4}$ Using their senses of sight and touch, the Omani workmen perceived the attributes of these objects based upon their size, stone quality, and representative signatures of burnt remains, identifying them as incense burners similar to the modernday Arabian-style burners that they knew. Archeologists Serge Cleuziou and Maurizio Tosi wrote about the attributes of these objects in their summary report on the excavations, noting three key points. First, when ascribing a domestic function to the object, they suggested that, "the sandstone burner was by no means a precious or exceptional object, but an item of standard household equipment: the burning of aromatics was an everyday activity performed with locally manufactured

3 Igor Kopytoff, "The Cultural Biography of Things," in The Social Life of Things: Commodities in Cultural Perspective, ed. Arjun Appadurai (Cambridge: Cambridge University Press, 1986), 66.

4 Serge Cleuziou and Maurizio Tosi, "Ra's al-Jinz and the Prehistoric Coastal Cultures of the Ja'alan," Journal of Oman Studies 11 (2000): 54. As Cleuziou and Tosi describe it, "the Early Bronze Age settlement at RJ-2 was a seasonal settlement of a fishing community occupied from fall to the spring, when fishing was not limited by the monsoon. This can be inferred from the microstratigraphic study of the deposits inside the houses and from general considerations. Due to heavy southern monsoon winds, offshore fishing is impossible in summer at Ra's al-Jinz ... the fishing season ranging from October to March" (41). objects in common use." Second, describing the artifacts as incense burners due to the interior residue, they reported that " $\mathrm{t}]$ he burnt material formed a $3 \mathrm{~mm}$ thick crust, roughly oval in shape, with edges fading to a light brown coloration. At closer examination, the rest of the containing space revealed remnants of previous firings and tiny pockets of the same greasy deposit, suggesting that the surface had been scraped before the last burning. The object was then classified as an 'incense burner, listed with number DA 12728 in the inventory of the Department of Antiquities of the Sultanate of Oman."6 Third, after interrogating their attributions, they re-emphasized the value of these objects in terms of their function, which helped understand their original purpose in the Arabian culture: "The close similarity in size and shape of these Bronze Age burners with those traditionally used for aromatics throughout Arabia until today strongly suggests that they too were in similar widespread use for daily household and ritual activities." ${ }^{7}$ While the excavators were first unable to determine the type of objects that they had found, their Omani workers in the field recognized DA 12728 as "the earliest mabkhara," or incense burner, in archeological history, used to burn $l b n$, the milky-white crystalized substance known as frankincense. ${ }^{8}$

5 Ibid., 54. The authors also wrote: "Fragments of two identical vessels had already been recovered from $\mathrm{RJ}-2$ in previous seasons, but they had not yet been identified as burners, due to their fragmentary condition. The first one, of the same shape (DA 10850), was found in the fill of pit su.2500, disconnected by erosion from the main sequence, while the second one is just a leg and part of a side (DA 11971) but comes from a safer context: su.3154 in Room IV of Building VI."

6 Ibid., 53-54.

7 Ibid., 54.

8 Ibid. For further discussion of the Semitic etymology of the root $l b n$, "white," from the Phoenician language, as well as a brief discussion of lbnt, "frankincense," see $\mathrm{He}$ brew in Its West Semitic Setting: A Comparative Survey of Non-Masoretic Hebrew Dialects and Traditions. Part I: 
By the late third millennium B.C., when the first incense burners started to be manufactured in Magan $^{9}$ (modern-day Oman and the United Arab Emirates), organized trade with Mesopotamia had intensified. By 2300 B.C., Ra's al-Jinz stood at the crossroads of an international system of complex exchanges between the Arabian Peninsula and the empires of Mesopotamia. ${ }^{10}$ The site was rich in Harappan pottery sherds, which bears testimony to the long distance trade between Mesopotamia, the lands of ancient Magan, and the Indus Valley to the east. ${ }^{11}$ The incense burners that Cleuziou and Tosi found at Ra's al Jinz were the first rectangular stone forms with four legs in archaeological history. ${ }^{12}$ The intact form DA 12728 is not only the oldest known cuboid incense burner in Arabia but also a fully intact exemplar from a well-defined and clear archaeological context (fig. 1.4). It was discovered in a deposit beneath and sealed by a layer of bricks and clay from the fallen walls surrounding it. Its position suggests that this burner was left behind in a corner of the room, with tools to be used during the next season. Two fragments of identical fourlegged containers were also found at Ra's al-Jinz in the previous seasons: the first one, DA 10850, in the

A Comparative Lexicon, Section Bb-Root System, Comparative Material and Discussion. Section $C, D$, and E, Numerals under 100-Pronouns-Particles, ed. Aimo Murtonen (Leiden: Brill, 1990), 244. See also an example of a large cuboid incense burner found at Lachish inscribed with the word, lbnt, i.e., "frankincense" in the Aramaic language in William F. Albright, "The Lachish Cosmetic Burner and Esther 2: 12," in A Light unto My Path: Old Testament Studies in Honor of Jacob M. Myers, ed. Howard N. Bream, Ralph D. Heim, and Carey A. Moore (Philadelphia: Temple University Press, 1974), 27. This is the ancient name for the South-Eastern region of the Arabian Peninsula in Bronze Age cuneiform texts.

Cleuziou and Tosi, “Ra's al-Jinz and the Prehistoric Coastal Cultures of the Ja'alan," 23-24. Ibid., 23-24. Over ninety-eight sites within a fourkilometer radius of $\mathrm{RJ}-2$ have been identified ever since, revealing a network of maritime settlements within South Asia's reach.

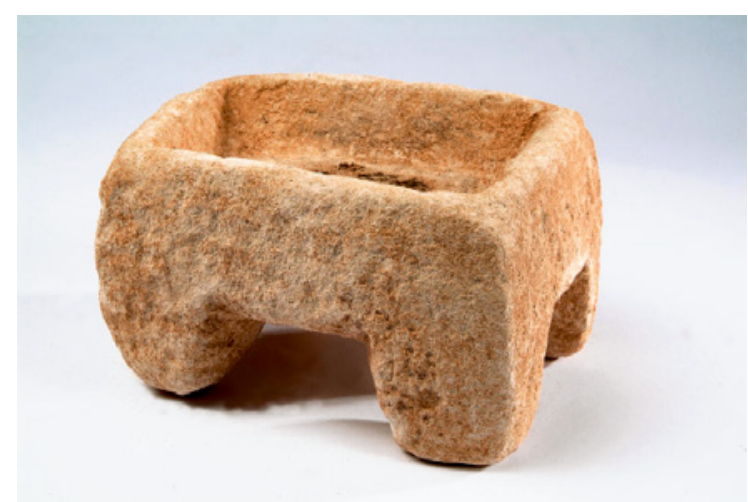

FIGURE 1.3 Cuboid incense burner DA12728, Ra's al-Jinz, Sultanate of Oman.

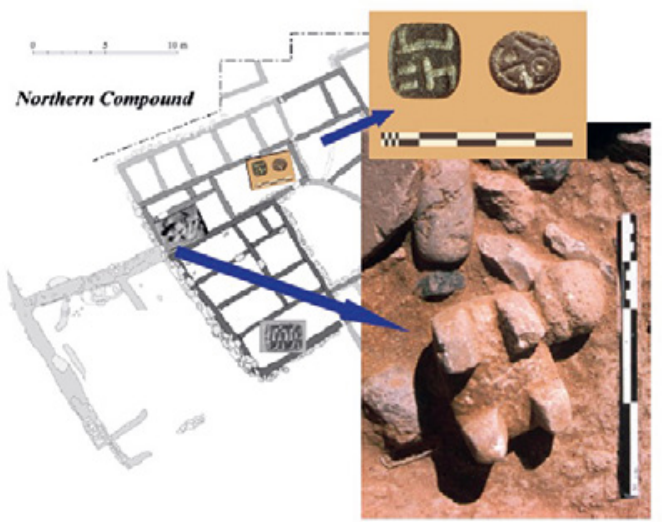

FIGURE 1.4 Cuboid incense burner DA12728, Ra's al-Jinz, found in situ from Building XI, Room 9, with Harappan seal impressions from Building VII, Room 8.

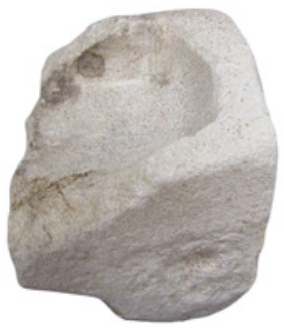

FIGURE 1.5 Cuboid incense burner fragment DA10850, Ra's al-Jinz.

fill of a pit, and the second one, the leg and side of another incense burner, in Room IV (DA 11971) (fig. 1.5). The incense burners were plain and displayed no signs of decorative incisions or carvings. 
When the rectangular burner DA 12728 was recovered from the northern domestic compound at $\mathrm{RJ}-2$, it was dug out of the ground upside down. Once the excavators rotated the container, they found a black greasy residue deposit in its center. The residue described by Cleuziou and Tosi was tested and identified as being burnt Boswellia sacra, presumably from Dhofar, the region where frankincense is cut from the bark of the trees growing there. ${ }^{13}$

\section{Third-First Millennium B.c.: "Aromatics of All Kinds" under the Axial Age of Empires}

Prior to the discovery of incense burners at Ra's al Jinz II, Assyriologists and Western archaeologists did not define these small devices as anything but four-legged troughs or boxes. ${ }^{14}$ By 1903, the German Oriental Society had identified at least one of the incense burners from Babylon with residue as

13 Personal communication with Dr. Maurizio Tosi in Salalah on June $28,2014$.

14 Leon Legrain, Terra-Cottas from Nippur (Philadelphia: Publication for the University Museum by University of Pennsylvania Press, 1930), 19; pl. 65. For a background on the aromatics trade in Mesopotamia, see Charles Franklin Myer, "The Use of Aromatics in Ancient Mesopotamia" (PhD. diss., University of Pennsylvania, 1975), and A. Leo Oppenheim, "The Seafaring Merchants of Ur," Journal of the American Oriental Society 74 (1954): 6-17. Thirty years prior to the Ra's al Jinz discoveries, the renowned Assyriologist and historian of Mesopotamia A. Leo Oppenheim defined the complex overland and maritime trade involving the Lower and Upper Euphrates River system as the main trade conduit from Arabia-India into the northern Levant. Oppenheim never connected any incense burners with the trade in aromatics, nor did he cite any evidence from Mesopotamia about the trade and exchange of frankincense from Arabia, but other Assyriologists before him, such as Leon Legrain and Leonard Woolley, briefly mentioned clay incense burners and recognized that they were instrumental for the burning of aromatics in Babylonia. an "altar " (Bab 28490). ${ }^{15}$ The German archaeologist Liselotte Ziegler finalized the identification when she published her line drawings of the objects in question by their Sumerian designation, NíG.NA, a nomenclature for fire-burners often listed in witchcraft literature that identified them as "fire-boxes," or raucherkästchen in the German language. ${ }^{16}$ Since then, over two hundred incense burners fashioned from clay in cuboid form have been identified, studied, and plotted. They are indicative of a widespread trade in aromatics that extended from the great cities of Ur, Nippur, and Babylon in southern Mesopotamia (the end of the Neo-Babylonian period and the beginning of the Achaemenid Persian period) to the settlements at the northern bends of the Euphrates River (modern-day Syria) (the Middle Bronze Age).

To be specific, these cuboid incense burners have been discovered during archaeological excavations of sites in southern and central Mesopotamia (fig. 1.6). Tall al-Muqayyar (Ur), Warka (Uruk), and Nuffar (Nippur) yielded the most burners, with as many as fifty from Uruk, thirty-seven from Nippur, and thirty-one from Tall al-Muqayyar. Sir Leonard Woolley identified them as clay incense burners in his 1962 report on the Ur excavations. ${ }^{17}$ Discovered from strata dated a century earlier in excavations from Syria, the earliest cuboid incense burners are from Tall Halawa, Mound A, and Tall Meskene Emar, settlements on the Euphrates River in modern-day Syria; one stone incense burner from the Larsa period was also excavated

\footnotetext{
15 I read this in the margins of the Babylon reports at the Vorderasiatisches Museum in Berlin.

16 Liselotte Ziegler, "Tonkästchen aus Uruk, Babylon und Assur" [Clay box from Uruk, Babylon, and Assur], Zeitschrift für Assyriologie 13 (1947): 224-40.

17 LeonardWoolley, UrExcavations IX. TheNeo-Babylonian and Persian Periods (London: Publications of the Joint Expeditions of the British Museum and of the University Museum, University of Pennsylvania, Philadelphia, to Mesopotamia. Published for the Trustees of the Two Museums, 1962), 103 .
} 

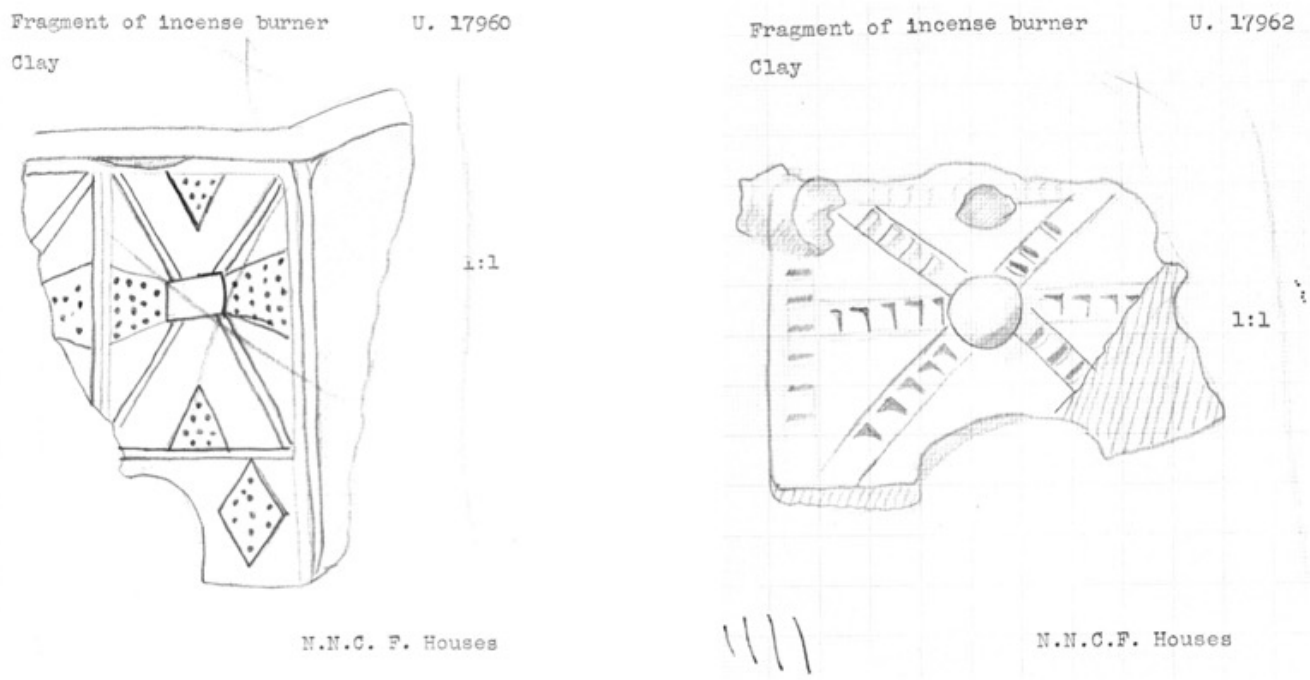

FIGURE 1.6 Cuboid incense burners from Sir Leonard Woolley's excavations at Ur, Iraq.

by Woolley at Ur (fig. 1.7) $1{ }^{18}$ Most of the thirty clay cuboid incense burners were found in domestic structures in the residential building Q, Level II, at Halawa; they date from the beginning of the Second Millennium, or the Middle Bronze Age I (ca. 1900-1700 B.C.). Seven incense burners were found inside private houses at the site, eight were excavated from the alleys facing these private houses, and five were found in the streets. The context for these fields was domestic, pointing to a culture for burning aromatics inside the home that extended geographically beyond what had been indicated in previous scholarship as Arabia's sphere of influence. The distribution pattern of these forms found at some of the conduit sites along the Upper Euphrates River suggests that the

18 See A. Pruß, "Räucherkästchen" [Incense burner], in Ausgrabungen in Halawa-3: Die Bronzezeitliche Keramik von Tell Halawa A [Excavations in Halawa-3: The Bronze Age pottery of Tell Halawa A], ed. Winfried Orthmann (Wiesbaden: Harrassowitz Verlag, 1994), 3:84, and J.-C. Margueron, "Le Coffrets" [Boxes], in Mission Archéologique de Meskéné-Emar: Dix ans des travaux:1972-1982 [Archaeological mission of MeskénéEmar: Ten years of work: 1972-1982], ed. Dominique Beyer (Paris: Éditions Recherche sur les Civilisations, 1982), 95-97. double mode of transportation-overland and maritime - created a rapid, safe, and efficient way to move commodities bidirectionally, especially before the advent of the domestication of the dromedary by the seafaring traders of Ur. ${ }^{19}$

Along these lines, other scholars have recognized and argued for the great awakening of the South Arabian trade that flourished later, in the First Millennium, during the time the dromedary was domesticated for long distance caravan trade. ${ }^{20}$ The increase in Arabian trading was undoubtedly the result of three important global transformations in the ancient Near Eastern economy prior to Islam. First, during the Babylonian king Nabonidus' reign in Tayma, the northern oasis of the Nabateans in the Arabian Peninsula

\footnotetext{
19 Oppenheim, "Essay on Overland Trade," 253.

20 See Ryan Byrne, "Early Assyrian Contacts with Arabs and the Impact on Levantine Vassal Tribute," Bulletin of the American Schools of Oriental Research 331 (2003): 11-23, and John S. Holladay, "Hezekiah's Tribute, LongDistance Trade, and the Wealth of Nations c. 1000-600 B.C.: A New Perspective," in Confronting the Past: Archaeological and Historical Essays on Ancient Israel in Honor of William G. Dever, ed. Seymour Gitin, J. Edward Wright, and J.P. Dessel (Winona Lake: Eisenbrauns, 2006), 312-15.
} 


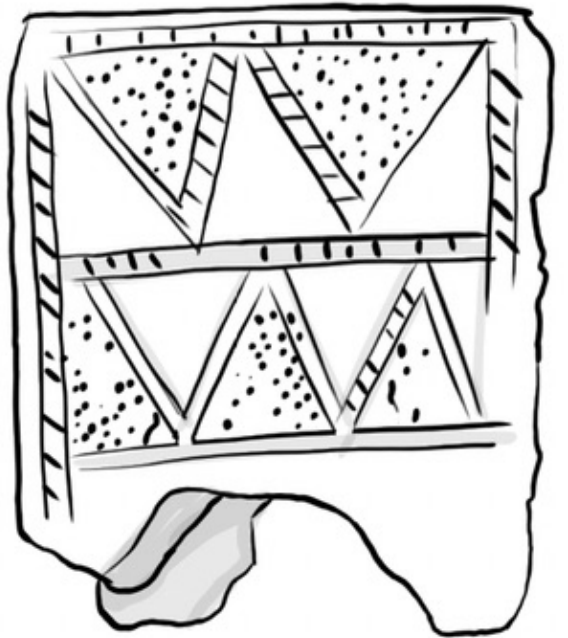

FIGURE 1.7 Incense burner from Ur-Larsa Period (UM U.6812).

(ca. 556 в.c.), the trade in aromatics intensified because of the Neo-Babylonian empire interacting with southern Arabia through the northern Arabian traders and Aramaic-speaking tribes. It is likely that Nabonidus single-handedly rerouted the flow of commodity exchanges from northern Arabia (Tayma) to Babylonia by the sixth century B.c. by penetrating into the desert, thus increasing the output of frankincense cultivation exponentially and passing it into the hands of traders and traffickers. ${ }^{21}$ Second, as the short-lived Babylonian empire eventually waned in power, the successive Mesopotamian empire would give way to the Kingdom of Persis in the south-western region of the Iranian Plateau in the First Millennium B.c. The Persians would reunite the lands by building and maintaining royal roads that strengthened the network of trade in commodities across a vast terrain from as far as Susa to North Africa. To their credit, by seizing control of the spice trade in the sixth century, the Persians established new royal roads and taxations across their empire, ef-

21 Paul-Alain Beaulieu, The Reign of Nabonidus, King of Babylon (556-539 в.c.) (New Haven, CT: Yale University Press, 1989), 174. fectively creating a "globalized" network system that reached the Mediterranean coast and the Aegean world.

In contrast to the first two events, the third deep historical transformation of the local economy was the successive rise of at least four major kingdoms inside the southern Arabian Peninsula that profited from the state-sponsored trade of frankincense and myrrh, the "petroleum" of the ancient world. These major kingdoms ruled successively in and around the oasis area of Hadramawt (Yemen), in the southern part of the Arabian Peninsula, and organized the transport of incense in the Iron Age, creating the historical memory of Arabia Felix. The kingdoms are classified by the written languages of their literate societies: Minaic, Qatabanic, Hadramitic, and Sabaic. Saba' (Sheba) was the most famous, wealthiest, and largest of the four, with its capital in Maryab (Marib). The kingdoms earned considerable profits by taxing, servicing, and protecting the camel caravans that led away from Arabia. They all developed marginally in the early or middle First Millennium B.C., before they advanced to city-state status in the middle to late First Millennium B.C.

These kingdoms were located on overland trade routes that led from the frankincense producing areas of Southern Arabia to the markets of the Near East and the Mediterranean. For example, the caravan route ran from the port of Qana, which was situated near the incense producing regions, to Shabwa, the capital of Hadramawt. Then, it continued around the edge of the desert into the cities of Timna and Marib, the capitals of Qataban and Saba', into Ma'in, the kingdom of spice merchants, and finally into Tayma, in northern Arabia. From here, it continued onto the southern cities of the Levant. Therefore, the spread of southern Arabian culture intensified in the mid-eighth century, during the Mukarrib period, which marked the zenith of the South Arabian (Sabaean) power. ${ }^{22}$ As a

\footnotetext{
22 Albert Jamme has defined mukarrib from the Arabic root karaba, meaning to "weave a rope," or to "strengthen connections." For details, see "Quelques problèmes
} 
result, Hadramawt, the region where frankincense groves grew, developed into a major trading center by the middle of the First Millennium B.c., after the Mukarrib period. By the third century в.C., a colony migrated from Shabwa to the Smhrm (Sumhuram) lagoon at Khor Rori, in Dhofar. ${ }^{23}$ From there, they exported frankincense under the protection and control of the Roman Empire.

Very little is known about the development of these kingdoms prior to the First Millennium в.C.; however, it is assumed that they developed over more centuries than we probably realize. Whatever the case may be, the wealth that the frankincense trade generated during the high period of royal rule helped to fund large-scale architectural building projects that required huge teams of quarry workers, stonemasons, and sculptors. Hence, the Marib architecture was the most spectacular of its time in Arabia for the mid-First Millennium: it included the Awwam temple (locally known as the Mahram Bilqis, or the Temple of the Queen of Sheba), the Bar'an temple, and the great dam of Marib, built in 550 B.C., a water management system for Saba' so impressive that it was mentioned in the Qurān (Süra 34:15-19). When the great dam burst in the seventh century A.D., it flooded Hadramawt, causing an environmental disaster and bringing a climactic end to the history of pre-Islamic South Arabia.

\section{$4 \quad$ Pack Animals: Arabian Dromedary}

Against this historical backdrop, the economic gain in revenue from the trade in aromatics increased in the First Millennium, under the protection of the Neo-Assyrians, intensified later under

sud-Arabes" [Some South-Arab problems], Biblica et Orientalia 12 (1955): 219-20. The mukarribs were localized in Saba' and their function was largely secular in nature. They ruled, waged war, and built public works and irrigation systems for frankincense cultivation. Juris Zarins, "The Latest on the Archaeology of Southern Oman," Journal of the American Oriental Society 129, no. 4 (2009): 665 . the Achaemenid Persians, and climaxed during the Roman rule, when new roads were created in response to the increased demand for exotic commodities, including new flavors and pleasant scents. However, navigating the elaborate system of relays and roads across arid environments required vehicles capable of sustaining these long and arduous journeys. Although donkeys were valued as pack animals capable of carrying heavy loads across mountainous terrains, camels gradually took their place as beasts of burden toward the end of the Second Millennium B.C., making long distance overland trade in desert areas possible. Although it is hard to determine when and where the dromedary was first domesticated along the coast of the Arabian Gulf, archaeologists have suggested that it happened toward the end of the late Third Millennium B.c. because of the camel bone collections found at Umm an-Nar, Hili 8, and Ra's Ghanda in the Arabian Peninsula. ${ }^{24}$ North of the Arabian Peninsula, the case for domestication is more difficult to make since the many archaeological sites have evidenced only low numbers of dromedary faunal bones, making the evidence for the domestication of camels in the Levant circumstantial. Establishing domestication requires substantial faunal remains to determine a reduction in average size. The zooarchaeological data available today shows a distribution of camel bones at Late Bronze Age II levels at Izbet Sartah and Tell Jemmeh, in the southern Levant, and at sites along the northern incense relays to Gaza, ca. twelfth and eleventh centuries A.D. ${ }^{25}$ Although it is unclear from such remains whether the camels were wild or domestic, the latest evidence for dromedary domestication suggests that the evolution of domestication was gradual, taking place over a few hundreds of years in the ancient Near East. By culling the assemblages of faunal remains

\footnotetext{
24 Brian Cotterell and Johan Kamminga, Mechanics of Pre-Industrial Technology (Cambridge: Cambridge University Press, 1990), 194.

25 Paula Wapnish, "Camel Caravans and Camel Pastoralists at Tell Jemmeh," Journal of Ancient Near Eastern Studies 13 (1981): 101-21.
} 


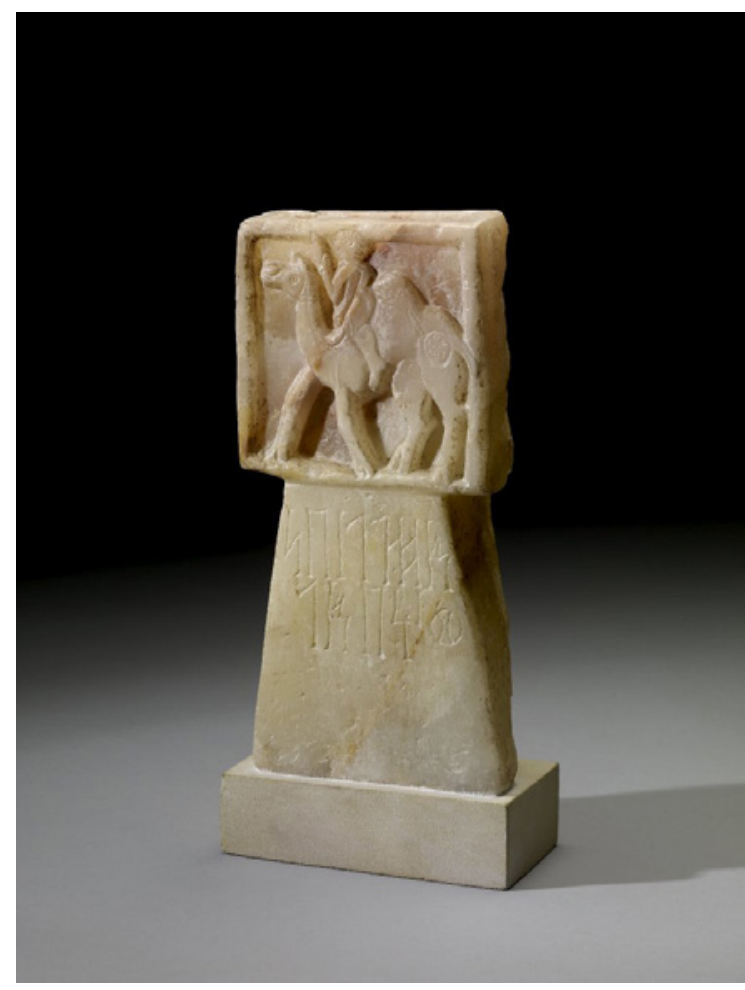

FIGURE 1.8 Incense burner from Shahbwa, Yemen (BM 125682; 1937, 0507.1).

at various sites, Caroline Grigson summarized the bulk of this evidence as follows: "Presumably in the earliest stages of domestication camels were exploited for their meat, milk and other products; their use for riding and in transportation of heavy goods and the subsequent realization of the possibilities for long-distance trade would have been a gradual development lasting many hundreds of years." 26

Even though the domesticated dromedary and the aromatics trade were entangled by the middle of the First Millennium B.C., as evidenced by a late third century B.C. incense burner from Shabwa (Yemen) held at the British Museum (fig. 1.8), small cuboid incense burners seem to have been locally

26 Caroline Grigson, "Camels, Copper and Donkeys in the Early Iron Age of the Southern Levant: Timna Revisited," Journal of the Council for the British Research in the Levant 44, no. 1 (2012): 97. made and rarely transported beyond short relays. ${ }^{27}$ Although they were easily stackable because of their size and square shape, traders would have not profited from the sale of incense burners themselves, as the weight of the containers, whether made by stone or clay, would have outweighed the benefit of the transaction. Indeed, it was the aromatics themselves that were the more precious commodities for trade.

Frankincense was undoubtedly the keystone commodity of South Arabian trade during the Iron Age, with up to 1,700 tons reaching the Mediterranean Sea during the Classical period under the Roman maritime rule. ${ }^{28}$ By the early First Millennium A.D., the price of frankincense is recorded in the annals of Roman history. Historian Pliny the Elder, for instance, calculates the cost of sending frankincense on the back of dromedary across the Arabian desert in his Naturalis Historia, an extensive thirty-seven volume encyclopedia and a primary source for understanding flora growing from various landscapes and cultures throughout the Roman world. Here, Pliny lists useful information on the types of substances traded on the Roman market coming from the Arabian Peninsula, the Levant, and India. No doubt, one should be

27 William G. Zimmerle, "Aromatics of All Kinds: Cuboid Incense Burners in the Ancient Middle East from the Late Third to the Late First Millennia B.c." (PhD diss. University of Pennsylvania, 2014), 7. For scientific testing of the limestone incense burners, see Seung Ho Bang, Oded Borowski, Kook Young Yoon, and Yuval Goren, "Local Production and Domestic Ritual Use of Small Rectangular Incense Altars: A Petrographic Analysis and Examination of Craftsmanship of the Tell Halif Incense Altars," in Gods, Objects, and Ritual Practices, ed. Sandra Blakely (Atlanta: Lockwood Press, 2017), 171. See also Sterenn Le Maguer, "Typology of Incense Burners from the Islamic Period," Proceedings of the Seminar for Arabian Studies 41 (2011): 173. Le Maguer came to the same conclusion that the clay incense burners of the Islamic period were locally made as Zimmerle concluded for the pre-Islamic forms.

28 Susan Ashbrook Harvey, Scenting Salvation: Ancient Christianity and the Olfactory Imagination (Berkeley: University of California Press, 2006), 35. 
suspicious of Pliny's rhetorical ethos and knowledge of the outside world beyond the Roman Empire, but it is remarkable how accurate he is regarding frankincense. For instance, he rightly suggests that: (1) myrrh grew separately from frankincense; (2) there were two harvests yearly and separately for frankincense and myrrh; and (3) that the frankincense district began after an eightday journey from Shabwa (Sabota). ${ }^{29}$ Additionally, as Pliny indicates, if traders followed the relays from southern Arabia to Gaza, they would have passed through a system of caravanserai and tolls along the way. In 137 A.D., he reports that the customs regulations of Palmyra specified 25 Denarii tax for every camel load of aromatics, and that these aromatics were transported in bags or sacks $^{30}$ while the oils were transported in alabaster jars or bottles. ${ }^{31}$ Indeed, the rise of an extensively "globalized" perfume trade from the Second Millennium into the First Millennium required such containers to transport hard gum resins and liquid-based commodities across the landscape.

29 Pliny the Elder, Natural History. Volume IV: Books 12-16. Translated and edited by H. Rackhman. Loeb Classical Library (Cambridge, MA: Harvard University Press, 1938).

William D. Glanzman, "Arts, Crafts, and Industries," in Queen of Sheba. Treasures from Ancient Yemen, ed. St. John Simpson (London: British Museum, 2002), 111. For depictions of leather bags in Neo-Assyria, see Max Mallowan and Lerri Glynne Davies, Ivories in Assyrian Style: Commentary, Catalogue, and Plates. Ivories from Nimrud (1949-1963) (London: The British School of Archaeology in Iraq, 1970), pl. XxIII.

31 A complete study of the distribution patterns for alabaster jars and bottles of South Arabia-type has yet to be completed. For some examples of "bee-hived" jars, see Carl S. Phillips and St. John Simpson, "Ancient South Arabian Softstone Vessels from the British $\mathrm{Mu}$ seum," in Softstone: Approaches to the Study of Chlorite and Calcite Vessels in the Middle East and Central Asia from Prehistory to the Present, ed. D. Kennet and St J. Simpson (Oxford: Archaeopress, 2018), 167-79. For examples of sqat jars, see Ann Searight, Julian Reade, and Irving Finkel, Assyrian Stone Vessels and Related Material in the British Museum (Oxford: Oxbow, 2008), 78.
Crystalline hardened gum resins required lighter and cheaper packaging to be carried onto the backs of camels, so leather bags were manufactured because they were lighter and more durable than stone bottles.

Most of the Neo-Assyrian kings recognized the value of the dromedary for carrying the heavy sacks of aromatics, or, as the annals frequently list them, "aromatics of all kinds" (Akkadian, riqqū kālama; Sumerian, ŠIM.ME ̌̌ and ŠIM.HI.A). ${ }^{32}$ The Arabian camel or dromedary is first mentioned in Neo-Assyrian inscriptions in the sixth regnal year of Tukulti-Ninurta (890-884 B.C.), as well as in the inscriptions of Ashurnasirpal II (883-859 B.C.). At least two other examples from the late Neo-Assyrian annals provide some of the best textual evidence about carrying aromatics out of Arabia. The Neo-Assyrian rulers Tiglath-Pileser III (745-727 B.C.) and Esarhaddon (681-669 B.c.) listed in their annals the tribute taken from Arabian queens and Aramaic kings, respectively. In the case of Tiglath-Pileser, this tribute included 5,000 pouches of all kinds of aromatics. In the case of Esarhaddon, the tribute is described in the following terms: "I added sixty-five camels (and) ten donkeys to the previous tribute and imposed [it] on him. Hazael died and I placed Iata', his son, on his throne. I added ten minas of gold, one thousand choice stones, fifty camels, [and] one hundred bags of aromatics [emphasis added] to the tribute of his father and imposed [it] on him. Later, Uabu, to exercise kingship, incited all of the Arabs to rebel against Iata."33

By the time of the early Roman Empire, the traffic in aromatics grew from raiding caravans to trading enterprises which led, in turn, to a very stable economy that flooded the region with commodities of all kinds. Some of the many types of ar-

The Assyrian Dictionary of the Oriental Institute of the University of Chicago, Volume 14, R, ed. Erica Reiner and Martha T. Roth (Chicago: Oriental Institute, 1999), 370. Erle Leichty, The Royal Inscriptions of Esarhaddon, King of Assyria (68o-669 в.c.) (University Park, PA: Penn State University Press, 2011), 19, 30, 38, and 49. 
omatics traded are reflected on the incense burners from Southern Arabia themselves. Many Southern Arabian incense burners from Hellenistic-Roman times found in Yemen (third century B.C. to third century A.D.) are inscribed with scent-notes; the high, middle, and low chords of scents are identified by their Semitic names for botanical aromatics, such as $q s t, l d n, d r w$, and $k m k m$. In the inscriptions on the artifact provided, qst, or Saussurea costus, grew in the Indus Valley and the Himalayas, while ldn, $k m k m$, and drw of the Pistacia genera were all highly suited to the wetter climate of the Mediterranean (fig. 1.9). Other aromatic names depicting fragrances, including rndm (nard) and lbny (frankincense or storax), were inscribed on some samples of cuboid incense burners. ${ }^{34}$ As many as fifty known examples of inscribed burners are part of museum collections. ${ }^{35}$ The suffix of lbny could indeed be the Old South Arabian singular adjectival nisbah for "whiteness," and the full word might have been employed descriptively to identify either frankincense or storax. ${ }^{36}$ Both these aromatics are shaded white and were often confused in

34 Joan Copeland Biella, Dictionary of Old South Arabic, Sabaean Dialect (Winona Lake, IN: Eisenbrauns, 2004), 93. Biella lists the following four aromatic notes on incense burner C683 as an example: rnd (nard), $d \underline{h} b$ (golden incense), $n^{\prime} m$ (sweet), qst (costus).

Mohammed Maraqten, "A New Small Incised Cuboid Incense Burner from Yemen," in "My Life Is Like the Summer Rose," Maurizio Tosi e l'Archeologia come modo di vivere: Papers in Honour of Maurizio Tosi for His yoth Birthday, ed. C.C. Lamberg-Karlovsky and B. Genito (Oxford: Archaeopress, 2014), 488.

36 Walter W. Muller, "Notes on the Use of Frankincense in South Arabia," Proceedings of the Seminar for Arabian Studies 6 (1976): 124-27. Muller has always argued for storax (Arabic lubnā) on the basis of Semitic etymology but given the general confusion in identifying these aromatics visually, there is no reason to definitely concur with Muller. See also Kjeld Nielson, Incense in Ancient Israel (Leiden: E.J. Brill, 1986), 18. On the contrary to Muller, Nielson writes, "lbny is undoubtedly Arabic lubān or frankincense. The final yod seems to be a nisbe construction indicating an adjective of relation." antiquity, as they are today. A three-legged round incense burner found at Khor Rori in Dhofar, the land of frankincense, was found to contain residue from the Pinaceae (pine) family, or Pistacia genera, which the scientists suggested to have originated from the Mediterranean area. ${ }^{37}$ The circular, legged limestone incense burner is from the first or second century A.D. Stone cuboid and circular clay incense burners from Tayma (fig. 1.10), a site lying along the northern relays of the aromatic trade, were also tested and found to contain residue from Boswellia sacra (frankincense). These incense burners were excavated from first or second century A.D. Nabataean Roman houses at the site of Tayma in the northern Arabian Peninsula. ${ }^{38}$

Besides the material culture of small cuboid incense burners, Classical mythmaking also described the travels and travails of finding and extracting Arabian gum resins, such as frankincense and myrrh. In the twentieth century, William F. Albright defined the relationship between myrrh and its altar in the First Millennium B.C. as divinized. ${ }^{39}$ This relationship was further exemplified

Erika Ribechini and Maria Perla Colombini, "Chemical Investigation of the Resinous Material from Sumhuram," in A Port in Arabia Between Rome and the Indian Ocean $3 r d$ C. BC to 5 th C. AD. Khor Rori Report 2 (Arabia Antica 5), ed. Alessandra Avanzini (Rome: L'erma di Bretschneider, 2008), 687-89. The main peaks were identified as didehydroabietic acid, dehydroabietic acid, and 7-oxo-dehydroabietic acid; the diterpenoid acid with abietane skeletons are the featured markers for the Pinaceae family. Incense Burner $\mathrm{S}_{4} 87$ (cat. 20). Barbara Huber, Arnulf Hausleiter, Michèle Dinies, Jan Christopher, Ina Säumel, and Thi Lam Huong Pham, “Tayma, Saudi-Arabien Interdisziplinäre Untersuchungen von Räuchergefäßen zur Rekonstruktion antiker Gerüche" [Tayma, Saudi Arabia interdisciplinary studies of smoking vessels for the reconstruction of ancient smells], e-Forschungsberichte, no. 2 (2018): 120, 123-24. William Foxwell Albright, Yahweh and the Gods of $\mathrm{Ca}$ naan: A Historical Analysis of Two Contrasting Faiths (London: School of Oriental and African Studies, 1968), 147 . 


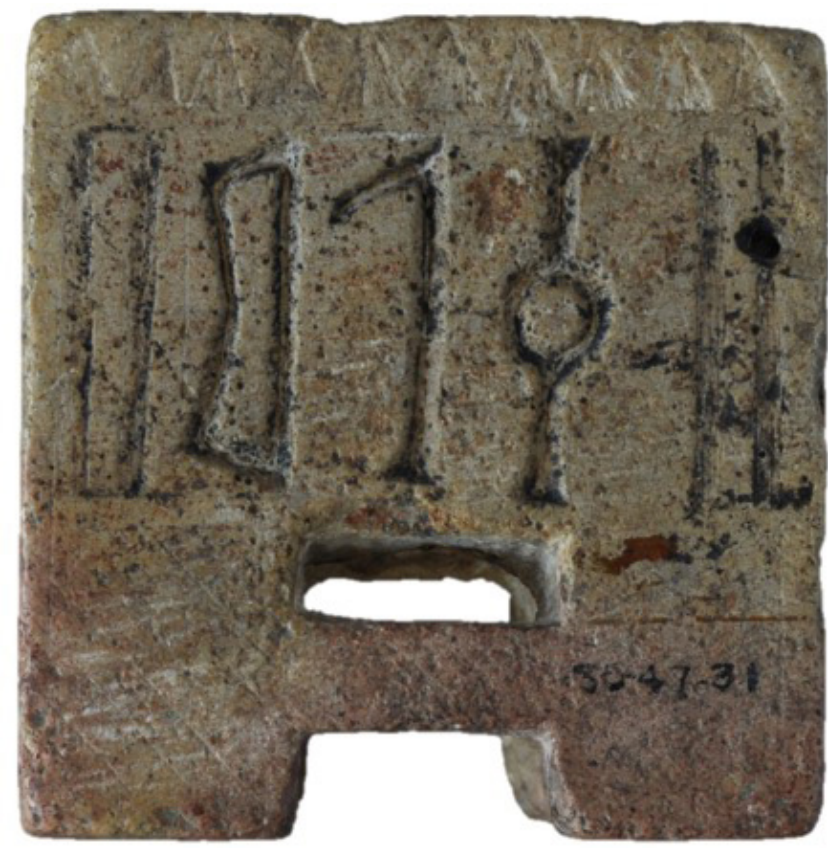

FIGURE 1.9 South Arabian incense burner inscribed with four scent notes in Old South Arabian as $l d n, \mathrm{~km} \mathrm{~km}, \mathrm{drm}$ and $q s t$ (UM Philadelphia 50-47-31).
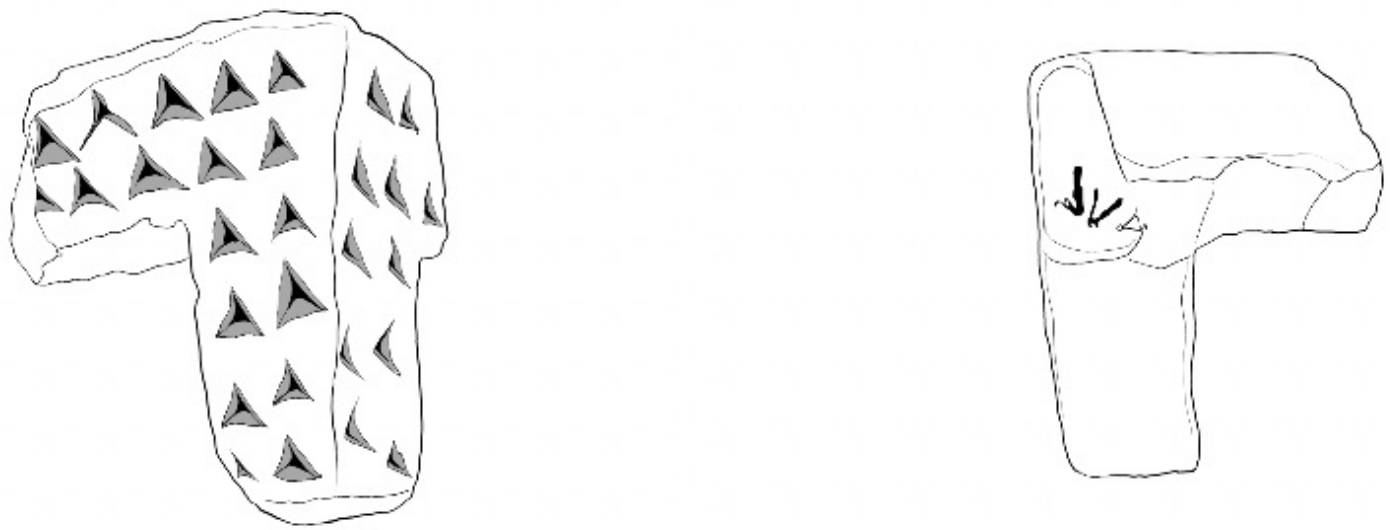

FIGURE 1.10 Fragment of an incense burner leg, Tayma Museum of Archaeology and Ethnography, K.S.A. 
through exchanges between the Mediterranean world and the Arabian Peninsula, and was best expressed in the fifth century B.C. Greek hymn to Myrrha (or Smyrna), the Cyprian princess whose mother compared her to the goddess Aphrodite. ${ }^{40}$ In the myth, the offended goddess caused Myrrha to fall in love with her own father because of jealousy, which resulted in an incestuous relationship between the two. When her father pursued her into the Arabian Peninsula, Aphrodite turned Myrrha into a myrrh tree. Her tears formed from scraping back the bark of the aromatic gum resin tree that produces myrrh. In a way, such a mythopoeia tries to explain why the etymological root of $m r r$ in Semitic languages is "bitterness," which characterizes the taste of myrrh-drops. Additionally, the historian Herodotus recounts the process of smoking the trees in Arabia by using a chemical agent - storax - as a means to chase away the flying serpents from the frankincense groves. ${ }^{41}$ Those myths point to a lesser known fact about cultural contact in the late First Millennium B.C.: the overland relays and roads of the Arabian Peninsula were bidirectional, just like the maritime routes of Arabia-Mesopotamia discussed previously, and were safeguarding some of the traditional knowledge of Arabia for financial gain through the telling of its myths to ward off trespassers and travelers from afar.

40 Marcel Detienne, The Gardens of Adonis. Spices in Greek Mythology, trans. Janet Lloyd (Princeton, NJ: Princeton University Press, 1977), 3-4.

41 Herodotus, The Histories, trans. A.D. Godley (London: William Heinemann; New York: G.P. Putnam's Sons, 1928), 2:135; A Greek-English Lexicon, comp. Henry George Liddell and Robert Scott, 8th ed. (New York: Harper \& Brothers, 1897), s.v. “ $\sigma \tau \hat{\rho} \rho \alpha \xi$ ”; Irina VainovskiMihai, "A Pre-History of Orientalism: Herodotus' and Strabo's Image of Arabia," in A Festschrift for Nadia Anghelescou, ed. Andrei A. Avram, Anca Focşeneanu, and George Grigore (Bucharest: Editura Universităţii din Bucureşti, 2011), 534 .

\section{5}

\section{Islam and Christendom}

After the decline of the Southern Arabian kingdoms, the trade in frankincense continued and prospered under Christendom. In a sense, outside Arabia, the place for burning incense moved from within the home to inside the church. Thus, incense is originally mentioned in the Nativity narratives of the New Testament. ${ }^{42}$ As Jesus was offered myrrh and wine on the cross in the Gospel of Mark, ${ }^{43}$ burnt incense became synonymous with martyrdom and the prayers of the Christian saints were lifted to the heavens by the smoke of the frankincense in daily piety practices. ${ }^{44}$ Inside Arabia, frankincense was still burned inside the homes as it was imperative to fumigate them with lubān and sage, according to Ahädith. ${ }^{45} \mathrm{Also}$, in order to enter inside the mosque, petitioners in prayer were required to present themselves to God clean and of good scent. ${ }^{46}$ Furthermore, both Christians and Muslims burned frankincense to ward off evil irritants through a complex interplay of smell, prayers, and magical incantations. ${ }^{47}$

\footnotetext{
42 Matt 2:11 (New Revised Standard Version).

43 Mark 15:23 (NRSV).

44 Harvey, Scenting Salvation, 13. Harvey quotes Psalm 141:2: "Let my prayer be counted as incense before thee, / And the lifting up of my hands as an evening sacrifice!"

Mohammed Farooqi, Ahadith Mein Mazkoor Nabatat, Adwiya Aur Ghizain [Maguiru in Ahdith, Adaviya and Gizhin] (Lahore: Ilm-o-Irfan Publishers, 1998), 151-52. Françoise Aubaile-Sallenave, "Bodies, Odors, Perfumes in Arab-Muslim Societies," in The Smell Culture Reader, ed. Jim Drobnick (Oxford: Berg, 2006), 392.

47 Bertram Thomas chronicled one example of this in Dhofar, Oman. See Bertram Thomas, "Anthropological Observations in South Arabia," Journal of the Royal Anthropological Institute of Great Britain and Ireland 62 (1932): 83-103. Thomas wrote: "These mountain tribes are much afraid of the Evil Eye, not only for themselves, but equally for their flocks and herds. The ceasing of lactation is invariably ascribed to Ain Balis. The cure is frankincense. I witnessed the ceremony on occasion and made a cinema film of it, though it is usually performed at sunrise or at sunset. The incense burner was
} 
From birth to death, from the home to the grave, frankincense played a pivotal role in one's life, either by providing pleasure and sweetness or by helping avoid painful irritants and malodors.

The trade in frankincense did not seem to dissipate in the aftermath of Christianity becoming the official religion of the Holy Roman Empire, as Patricia Crone argued in her book, Meccan Trade and the Rise of Islam. ${ }^{48}$ As a substantive point, Crone argued that frankincense was no longer the luxury of living that it once was in Pre-Islamic times. ${ }^{49}$ While acknowledging that the cause for this phenomenon can only partially be explained by Christianity's effects on the living, the evidence for frankincense being still in use at the time is substantial. ${ }^{50}$ Rather, the trade expanded in the opposite direction, where researchers found remnants of frankincense residue as far as the palace temple of Nanjing Chang Gan (ca. 960-1120 A.D.), a settlement lying just northwest of modern-day Shanghai in China. ${ }^{51}$ The organic materials found there were dated 1101 A.D., and two types of resins, wood-aloe and gum resin, were detected by gas chromatography-mass spectroscopy. Analysis also

brought and wood introduced and lighted. The practitioner, the cow-owner, broke a fragment of frankincense about the size of a walnut into three pieces. Then spitting upon it three times he introduced it into the burner. While two other witnesses held the afflicted animal by head and leg respectively, he waved about its head the burning frankincense, chanting a set sacrificial chant" (88).

Sterenn Le Maguer, "The Incense Trade During the Islamic Period," Proceedings of the Seminar for Arabian Studies 45 (2015): 176.

49 Patricia Crone, Meccan Trade and the Rise of Islam (New Jersey: Gorgias Press, 2004), 27. Le Maguer, "The Incense Trade During the Islamic Period," 176 .

Lei Zhouet, Dawa Shen, Junquan He, Yuhui Wei, Quinglin $\mathrm{Ma}$, and Zhide $\mathrm{Hu}$, "Multispectroscopic Studies for the Identification of Archaeological Frankincense Excavated in the Underground Palace of Bao'en Temple, Nanjing: Near Infrared, Midinfrared, and Raman Spectroscopies," Journal of Raman Spectrometry 43, no. 10 (2012): 1504-509. detected the presence of Boswellia, or frankincense. ${ }^{52}$ As in the Roman Empire, the trade in frankincense increased in the years following the rise and fall of the Han Empire (206 B.C.-220 A.D.) as the demand for exotic flavors increased, ultimately reaching the Far East by the tenth century A.D.

\section{Modern-Day Arabia: Scents and Notes on the Production of Cuboid Incense Burners}

Frankincense has been continuously used in the Arabian Peninsula for at least five thousand years. As a malleable gum resin, it can be chewed to sweeten foul breath, distilled and drunk as an antihistamine for respiratory problems, and burnt inside a kanūn (a large incense burner $)^{53}$ for celebration. When burned in the morning or in the early evening, the flaming scent and smoke of the gum resin would offer a hedge of protection against evil; however, when burned in midday, it could conjure the "eye of Shaytān." 54 The endurance of such practices over time indicates the sustainability of cultivated frankincense as a natural resource and medicinal agent with perceived cleansing power in the community, able to drive away foul spirits from the home and remove impurities from the body.

To burn frankincense, incense burners in clay forms are used: such burners are still crafted nowadays in the households of Dhofar, the Wilayat Governate in Oman, and throughout Yemen, including

It seems that the type of frankincense found was of the species usually grown in Ethiopia (East Africa).

The etymology of this word indicates an Arabic root meaning "to cover."

The "eye of Shaytān," or evil eye, is the belief that, under the influence of Shaytan (Satan), the glance of envious individuals may bring harm to others, intentionally or unintentionally. Islam emphasizes that the Holy Qur'ān has healing and protective powers, and recommends following the Islamic traditions to gain protection and cure. 


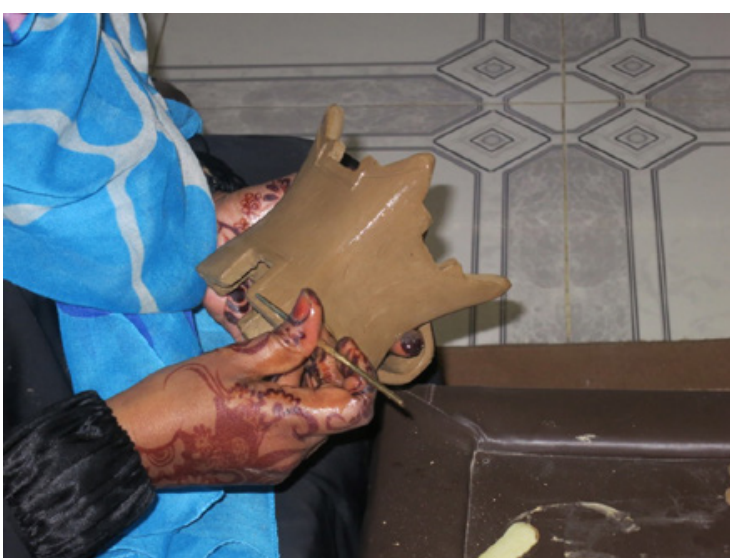

FIGURE 1.11 Cuboid incense burner with four legs and four horns from Dhofar.

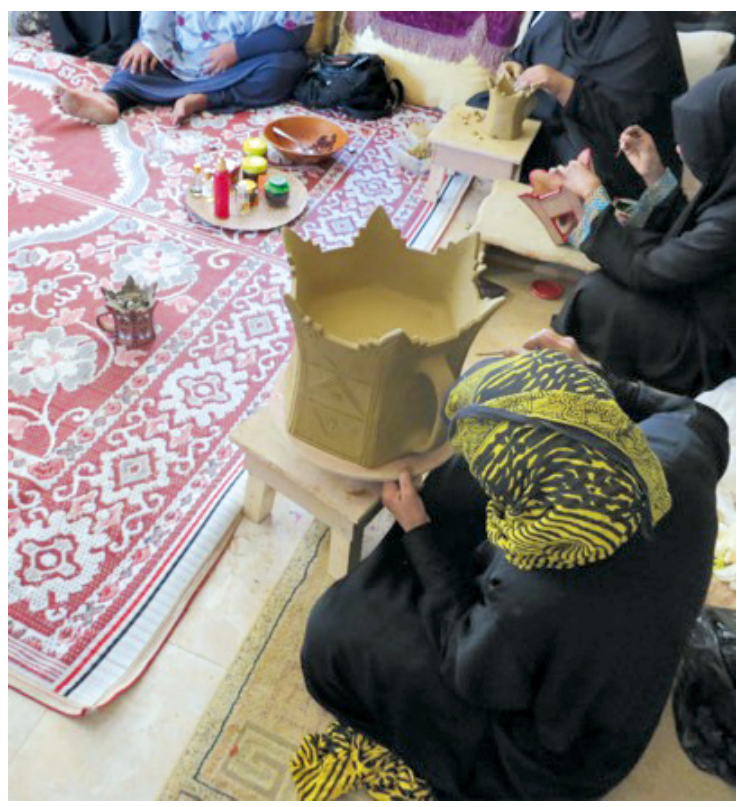

FIGURE 1.12 Craft training center in Salalah, Sultanate of Oman, where adults and children train to make incense burners.

the island of Socotra. ${ }^{55}$ These objects are worth studying as they provide useful information about the practice of making and using incense burners as heritage in the "land of frankincense" today, and show similarity in style to the shapes and designs of incense burners crafted in antiquity mentioned above. Incense burners from Dhofar,

55 Yemen is an interesting case as here most of the incense burners are made of stone, except for the clay forms made on Socotra Island. the land where frankincense trees grow, are generally cuboid, and called al-majmärah from the Arabic root gmr, or fire-coal. In the past century, these recipients included clay boats and, more recently, high heeled shoes, but the principal form used in the past was the cuboid shape. The forms have undoubtedly evolved from those found at Ra's al Jinz, but they have retained four legs with additional four horns at each corner of the cubes (fig. 1.11). ${ }^{56}$ In recent years, cheaper manufacturing techniques and newer designs have begun to undermine this traditional craft, yet, simultaneously, the growing support for making incense burners has proportionally raised the number of potters in Dhofar. ${ }^{57}$

The vertically-shaped incense burner with four horns is a design embedded into the Dhofari potters' mind from at least the early age of four or five (fig. 1.12). Interestingly, the potters have no knowledge of its earliest existence or of earlier histories of the al-majmärah at Ra's al Jinz and, when asked about their craft, they responded that they were taught it in the home. Children are taught that the square form with horns is the oldest and the only legitimate form for burning incense. ${ }^{58}$ Moreover, when interviewed, potters itemized the

56 Claire Hardy-Guilbert and Sterenn Le Maguer, "Chihr de l'encens (Yémen)" [Incense from Shihr (Yemen)], Arabian Archaeology and Epigraphy 21, no. 1 (2010): 21. Hardy-Guilbert and Le Maguer provide a preliminary typology based on the frankincense burners found at the site of al-Shihr in the Medieval Islamic period, which has a long chronological sequence (780-1996 AD). Some typological features can be discerned over time because of the site's stratigraphy and the number of incense burner forms found there. They include the lengthening or shortening of handles or the absence of fitted clay handles for holding these devices.

57 Since 2011, the Dhofar Ethnoarchaeology Preservation Project that I lead, sponsored by the Diwan of the Royal Court-Sultan Qaboos Cultural Centre, has studied the processes of incense burner manufacturing and use in the Sultanate.

$5^{8}$ William G. Zimmerle, Crafting Cuboid Incense Burners in the Land of Frankincense, Sultanate of Oman, trans. Jenan Awad Mahmood (Washington, DC: Sultan Qaboos Cultural Center, 2017), 23-27. 


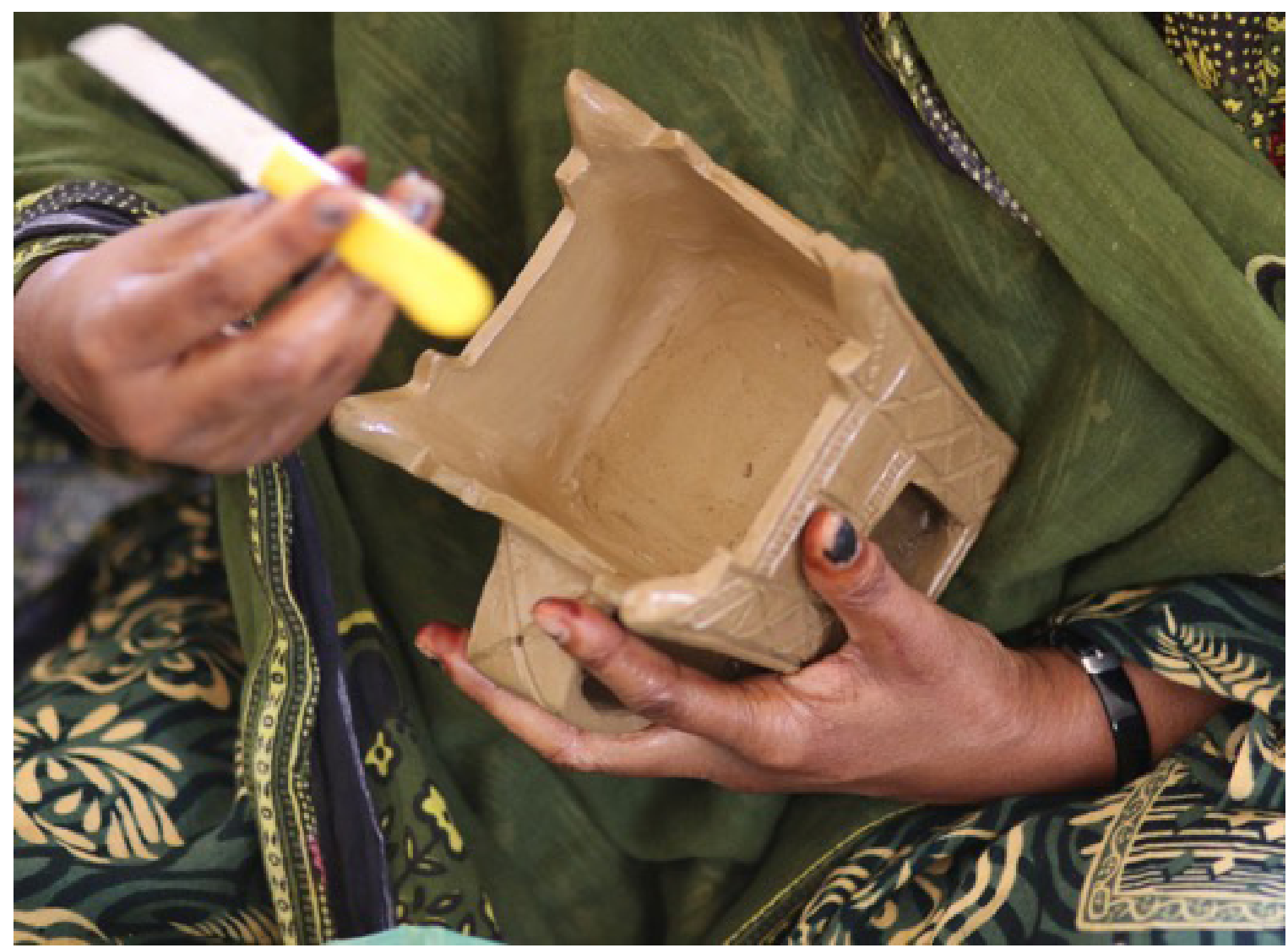

FIGURE 1.13 The "roof" of an incense burner as an architectural model from Dhofar.

process. The construction of the incense burner was demonstrated in conversation, and its form divided into multiple parts: the base, body, horns, handle, and face. Potters often spoke of the parts of the incense burner as they would talk about a person, or an extension of themselves. Furthermore, they defined each field of space by using specific terminology. For example, they referred to the basin of the incense burner as al-sateh. or the roof in Arabic, which designates the space between the crenellated horns, reinforcing the notion of the incense burner as an architectural model, with the designs culled from the mudbrick architectural environment (fig. 1.13).

Multiple steps were involved in the fabrication of the cuboid shape. ${ }^{59}$ The form was made

59 Ibid., 19. sequentially, from top to bottom. The potter manufactured the top half first by stretching the clay and molding it into a square basin, after which he molded and pinched the clay to form a base. The two pieces were eventually molded into one box-like form. Once the potter finished molding the two-part form into a unified square form, she began to create a set of architectural features for it, which helped to define its shape and function (fig. 1.14). First, she cut four windows for each form by using a knife: with it, she incised a set of vertical draft lines to mark off where she should cut (fig. 1.15). Once this step was completed, she proceeded to make a series of careful and steady incisions. Then, she removed the excess clay from the cuts and, interestingly, she reused it to make horns, and then pinched, twisted, and molded the clay pieces into four small horned projections that she attached to the cuboid. Using water to moisten 


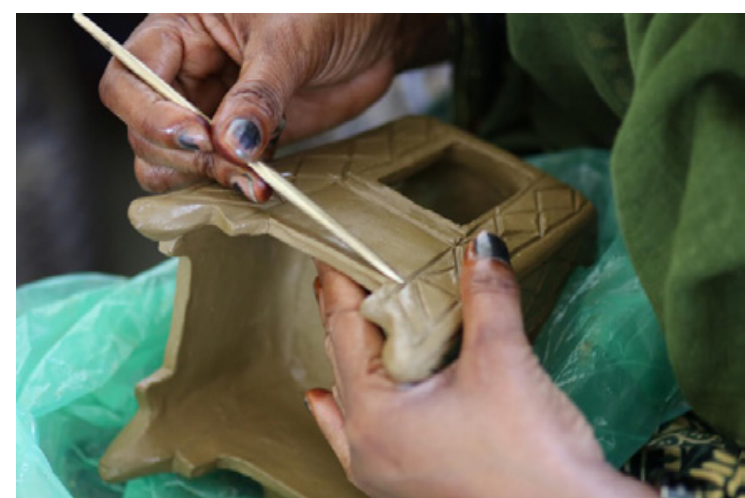

FIGURE 1.14 A potter designing an incense burner in Dhofar.

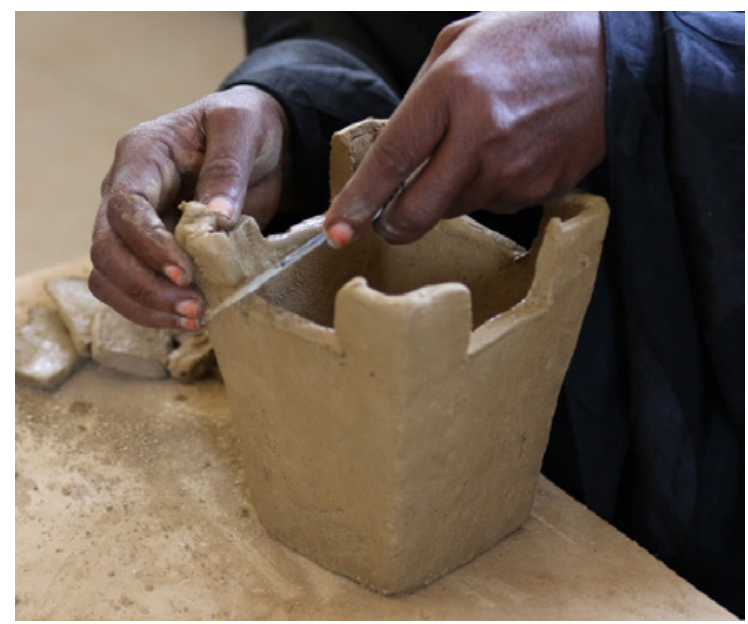

FIGURE 1.15 A potter cutting architectural features onto her Dhofari incense burner.

the clay, she reapplied the clay to each point of the incense burner. These observational sessions made it clear that potters do have a choice in the forming techniques that they use, but they may have wider latitude today than in the past in terms of what they make and how they make it. When I asked one of the female potters why she made horns for the incense burner, she explained that "it is not a majmar (incense burner) without the horns!"60 It is interesting to note that, on wedding days, the potters will often wear large horned incense burners of forty by fifty centimeters, full of

$60 \quad$ Ibid., 21.

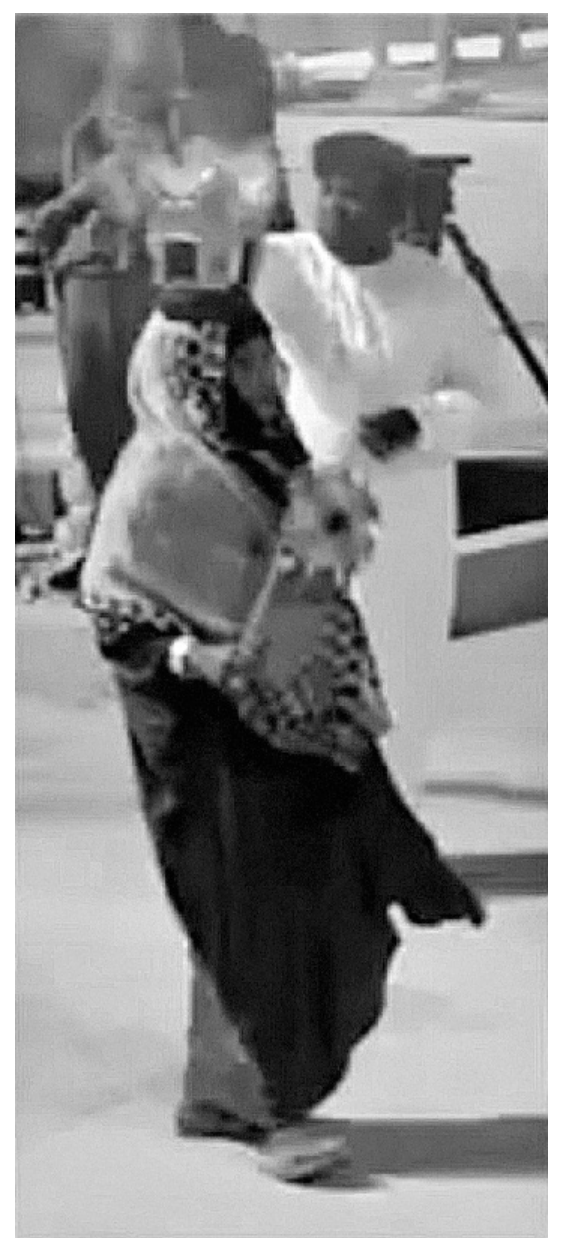

FIGURE 1.16 A Dhofari woman wearing an al-kanūn during a heritage festival, Sultanate of Oman.

burning frankincense. The device, known as alkanūn, is a horned crown full of burning frankincense worn by Dhofari women during holidays, parades, and festivals (fig. 1.16). It can be identified by its horned cuboid shape and burning frankincense wafting in the air.

Additionally, not only do potters make incense burners but also use local frankincense, placing it inside the incense burners of their houses. The women of Dhofar would recite prayers in the morning and in the evening before an incense burner. One such Dhofari prayer in Arabic and Jibbali (one of the modern languages of southern Arabia) is: "Frankincense (Ya lubān)! Frankincense (Ya lubān)! You, the one who is going to the 
heavens, keep away from us the enemy and protect us from the hatred of the friend and enemy." ${ }^{11}$ This prayer implies that the cuboid burner and its frankincense are not only used ritualistically inside the home, to invite pleasant smells, but also, depending on the context and timing of the day, to ward off evil, cure stenches, and remedy maladies. ${ }^{62}$ This ritualistic role of frankincense is confirmed by the historian Herodotus, who wrote that, "whenever a Babylonian has had intercourse with his wife, they both sit before a burnt offering of incense (Greek, thymímèma), and at dawn they wash themselves; they will touch no vessel before this is done. This is the custom also in Arabia." ${ }^{63}$ By the time Herodotus was writing his annals, perfumed incense was in high demand as the primary means to purify the body privately in the home. The practice could be witnessed both in Magan and Mesopotamia, where cuboid incense burners have been excavated. In this sense, as in the case of Dhofar today, everyday fumigation in the ancient world was indeed ritualistic: it could produce pleasure, protect the household from painful irritants, and remove malodors from the environment.

\section{Conclusion}

Textual evidence from both Classical and Ancient Near Eastern sources at the height of the famed Arabian incense trade suggests that specific aromatics were tied to particular geographic regions. Frankincense is one of the scents most commonly associated with the southern Arabian Peninsula. When Westerners envision Arabia or think of it

\footnotetext{
61 Ibid., 31.

62 In Scent from the Garden of Paradise: Musk and the Medieval Islamic World (Leiden: Brill, 2017), Anya King notes that "the frankincense and myrrh of Arabia had their uses in medicine, but they are not mentioned at all in the literature on luxury perfumery nor celebrated in poetry, indicating that they were thoroughly without any prestige value, though they were surely used by the common folk" (83).

63 Herodotus, The Histories, 1:198.
}

today, the thought of frankincense scent often comes to their mind for two obvious reasons: frankincense and myrrh have entangled themselves in their historical memory because of the influence of the Classical mythology and Christianity on Western civilization. Throughout the ages, Classical myths coupled with Christian narratives reminded readers and listeners of the twin fragrances of frankincense and myrrh through sensory experiences: either by seeing or hearing nativity narratives, or by smelling these scents during liturgical masses or services, when they were wafted over participants as cleansing agents of prayer. From those entangled memories grounded in religious practices, frankincense-myrrh have become the most obvious twin aromatics associated with the Arabian Peninsula, although within the markets of aromatic commodities they are only two of the many scents that have been cultivated and traded throughout history. The other types of scents are more difficult to determine due to their similar appearance in color and consistency with frankincense-myrrh, even though they were in wide circulation during the Hellenistic period, as evidenced by inscriptions of their names onto the sides of the cuboid incense burners found in archaeological excavations in Yemen.

How, then, do historians and archaeologists understand the movement of intangible culture such as the scent of frankincense? For one, the material correlates that are left behind can be used to reconstruct patterns of trade: we know where and when traders moved because the demand for aromatics increased the necessity to manufacture containers to cense ritual places, which explains the widespread distribution of one type of incense burner from the Arabian Peninsula. On another level of interpretation, when tested in the laboratory, the objects associated with these scents can also be used to identify the types of aromatics in circulation for long distance trade: in this case, the Arabian cuboidshaped incense burner bears strong testimony to a flourishing trade in frankincense throughout the Arabian Peninsula, and so the cuboid 
incense burner and frankincense are entangled in historical memory. ${ }^{64}$ This is not to suggest that

64 The Arabian Scents Project led by the author at New York University-Abu Dhabi has tested multiple incense burners from the middle to late First Millennium by using liquid chromatography-mass spectrometry. In multiple cases, the chemical features of frankincense (Boswellic acids-triterpenoid) were identified in late Mesopotamian incense burners from the Achaemenid Persian period. Therefore, it was determined that frankincense was in circulation in southern Mesopotamia during the Achaemenid Persian Empire (c. 550330 в.c.) (publication forthcoming). This should not be taken to imply that only frankincense was burned within the cuboid incense burners or that cuboidshaped burners are the only type of incense paraphernalia. Rather, it tells us that frankincense was indeed in circulation as one of the main aromatics of "all kinds of aromatics" in the sixth-fifth century B.C. This scientific evidence is another line of data available to analyze besides the textual sources reviewed in this chapter. other aromatics had not been burned inside the cuboid-shaped incense burner; however, it is evident that cultural and spatial contexts demanded incense to be burned in antiquity as it does today in Dhofar. On a third and final level, ethnographic fieldwork can help us define how an Arabian frankincense burner has evolved over time by comparing its contemporary form to excavated exemplars from archaeologically stratified sites.

As the principal containers for burning aromatics associated historically with the Arabian trade in scents, the incense burners found in excavation sites, alongside historical sources regarding the economy of incense trade in pre-Islamic Arabia, can help us answer the question: "Where does the censer come from and who made it?" In this case, the origin of the cuboid incense burner, just like some forms of Boswellia sacra, can be confidently traced back to the Arabian Peninsula where the scent of frankincense is found. 